Article

\title{
Effect of Seasonal Temperature on the Performance and on the Microbial Community of a Novel AWFR for Decentralized Domestic Wastewater Pretreatment
}

\author{
Juanhong Li and Xiwu Lu* \\ School of Energy and Environment, Southeast University, Nanjing 210096, China; li_juanhong1@163.com \\ * Correspondence: xiwulu@seu.edu.cn; Tel.: +86-25-8379-2614
}

Academic Editors: Faisal Ibney Hai, Kazuo Yamamoto and Jega Veeriah Jegatheesan

Received: 27 February 2017; Accepted: 5 June 2017; Published: 11 June 2017

\begin{abstract}
Due to environmental burden and human health risks in developing countries, the treatment of decentralized domestic wastewater has been a matter of great concern in recent years. A novel pilot-scale three-stage anaerobic wool-felt filter reactor (AWFR) was designed to treat real decentralized domestic wastewater at seasonal temperature variations of 8 to $35^{\circ} \mathrm{C}$ for 364 days. The results showed that the average chemical oxygen demand (COD) removal efficiencies of AWFR in summer and winter were $76 \pm 7.2 \%$ and $52 \pm 5.9 \%$ at one day and three days Hydraulic Retention Time (HRT), respectively. COD mass balance analysis demonstrated that even though COD removal was lower in winter, approximately $43.5 \%$ of influent COD was still converted to methane. High-throughput MiSeq sequencing analyses indicated that Methanosaeta, Methanobacterium, and Methanolinea were the predominant methanogens, whereas the genus Bacillus probably played important roles in fermentation processes throughout the whole operation period. The performance and microbial community composition study suggested the application potential of the AWFR system for the pretreatment of decentralized domestic wastewater.
\end{abstract}

Keywords: decentralized domestic wastewater; seasonal temperature; anaerobic wool-felt filter reactor; high-throughput MiSeq sequencing

\section{Introduction}

Water, land, and energy are important resources for the rapid growth and development of the global economy. However, in recent years, many developing countries face challenges and pressures of water and land pollution, and energy shortages. Particularly in rural areas of China, water pollution problems are increasingly aggravated due to the direct discharge of a large amount of untreated domestic wastewater [1,2]. Although centralized biological processes have been well developed to be used in urban municipal wastewater treatment plants, they are not suitable for rural areas owing to the dispersed population, poor wastewater collection, and weaker economy in these areas. In addition, a concept of wastewater-to-resource is receiving increased attention by researchers and engineers working on wastewater treatment technology development [3]. Therefore, it is highly desirable to select a sustainable, robust and cost-effective process for the treatment of decentralized domestic wastewater in developing countries [4].

Simultaneous energy recovery and sustainable wastewater treatment make the application of anaerobic biotechnology in decentralized domestic wastewater treatment interesting [5-7]. Upflow anaerobic sludge blanket reactors (UASB) [8,9], anaerobic baffled reactor (ABR) [10], and anaerobic membrane bioreactor (AnMBR) $[7,11,12]$ are commonly used to treat domestic wastewater. Despite the effective chemical oxygen demand (COD) removal by these anaerobic biotechnologies, some challenges still exist, such as complex three-phase separator and long solids' retention time of UASB, 
membrane fouling and high energy costs of AnMBR, and high land footprint of ABR. Compared to these high-rate anaerobic reactors, the anaerobic filters (AFs) have drawn attention because of the following advantages [13-15]: (1) simple design configuration with low capital and operating costs, (2) excellent capability of high biomass retention with carriers, (3) stable operation, (4) greater tolerance to hydraulic loading rate and organic loading rate, and (5) low footprint. The potential of using AFs for treating wastewater have been well developed not only for industrial wastewater, but also for domestic wastewater [5,16-18]. However, most of these studies focused on the effects of carriers, hydraulic retention time (HRT), and organic loading rate on the performance of AFs, and there were a few studies that focused on the effects of seasonal temperature $[5,18]$. Previous studies have demonstrated that anaerobic biotechnology strongly depends on operation temperature, and AFs are commonly operated under mesophilic conditions [5,19]. Nevertheless, considering the energy consumption and capital expenditure, it is economically unviable to heat anaerobic systems in decentralized domestic wastewater treatment of rural areas. Therefore, the application of AFs at seasonal temperature is more useful due to less energy demand. In context to China, this study is inevitable as the seasonal temperature varied throughout the whole year. Additionally, carriers are an important component of AFs, which determine the biomass retention capacity and the performance of the system. Therefore, the choices of appropriate carriers play an important role in AF system performance, particularly in the rural area of developing countries. A variety of natural materials, including zeolite [20], ceramic [21], rock $[5,22]$ and coconut shells [23] have been adopted as biofilm carriers. Even though these natural materials are low-cost, they are susceptible to clogging and require significant operation attention due to biofilm growth [22]. Wool felt is a class of natural porous materials that is a common waste product of paper making factories in China. Compared to solid materials, wool felt is a class of soft filler with a large specific surface area of about $950 \mathrm{~m}^{2} / \mathrm{g}$ that avoids clogging. Wool felt may be a viable option for AFs due to low cost and a large specific surface. Hence, wool felt has been applied before in a membrane reactor for the biosorption of heavy metals [24]. In response to those factors, a pilot-scale three-stage anaerobic wool-felt filter (AWFR) was designed to treat decentralized domestic wastewater.

It is well known that anaerobic biotechnology is a biological degradation process comprising mutual metabolic interaction among the bacterial and archaeal community. Microorganisms play important roles in the efficiency and stability of the anaerobic treatment [25]. However, most of the available studies have been operated as a "black box" without focusing on the role of the microbial communities [26]. To get comprehensive insights into the microbial community of the anaerobic process, molecular biology tools are used to determine the structures of the microorganisms in the system. To date, the molecular biology tools have been extensively developed. Nevertheless, most of the studies still applied the techniques of terminal restriction fragment length polymorphism (T-RFLP) [27], fluorescence in situ hybridization (FISH) [19,28], denaturing gradient gel electrophoresis (DGGE) [29-31] and quantitative polymerase chain reaction (q-PCR) [32]. Compared to the conventional ones, the high-throughput sequencing, especially Illumina MiSeq sequencing, is becoming one of the most popular molecular tools for microbial community analysis due to low-cost, fast turnaround time producing several gigabases of sequence and greater coverage [33]. Nevertheless, there is no study that focused on the microbial communities in the AWFR system.

The aim of this work was to evaluate the performance of a pilot-scale three-stage anaerobic wool-felt filter reactor (AWFR) in treating decentralized domestic wastewater seasonally. Additionally, this work also investigated the seasonal variations of microbial community in the AWFR system based on high-throughput MiSeq sequencing. The results provided a comprehensive understanding of the relationship between the microbial community and the performance of the AWFR system. 


\section{Materials and Methods}

\subsection{Experimental Setup and Operation}

The experimental studies were conducted in a pilot-scale three-stage AWFR made of polyvinyl chlorine polymer. Each identical AWFR has a height of $2.5 \mathrm{~m}$ and an internal diameter of $170 \mathrm{~mm}$ as shown in Figure 1. In order to avoid clogging, each reactor with the effective volume of $50 \mathrm{~L}$ was packed with vertical wool felt carrier as biomass growth support media. The wool felt carriers had a high specific surface area (about $950 \mathrm{~m}^{2} / \mathrm{g}$ ) with a high porosity $(>95 \%)$. The reactors were continuously fed with real decentralized domestic wastewater by using a peristaltic pump. Based on the seasonal temperature variations, the operation of the AWFR system was divided into five periods: start-up period ( $1-30$ day, $15 \pm 3.4{ }^{\circ} \mathrm{C}, n=30$ ), spring period (31-90 day, $21 \pm 3.0^{\circ} \mathrm{C}, n=60$ ), summer period (91-180 day, $\left.31 \pm 3.7^{\circ} \mathrm{C}, n=90\right)$, autumn period (181-270 day, $\left.25 \pm 5.2{ }^{\circ} \mathrm{C}, n=90\right)$ and winter period (271-364 day, $\left.10 \pm 2.2^{\circ} \mathrm{C}, n=94\right)$. The main operating conditions are summarized in Table 1 .
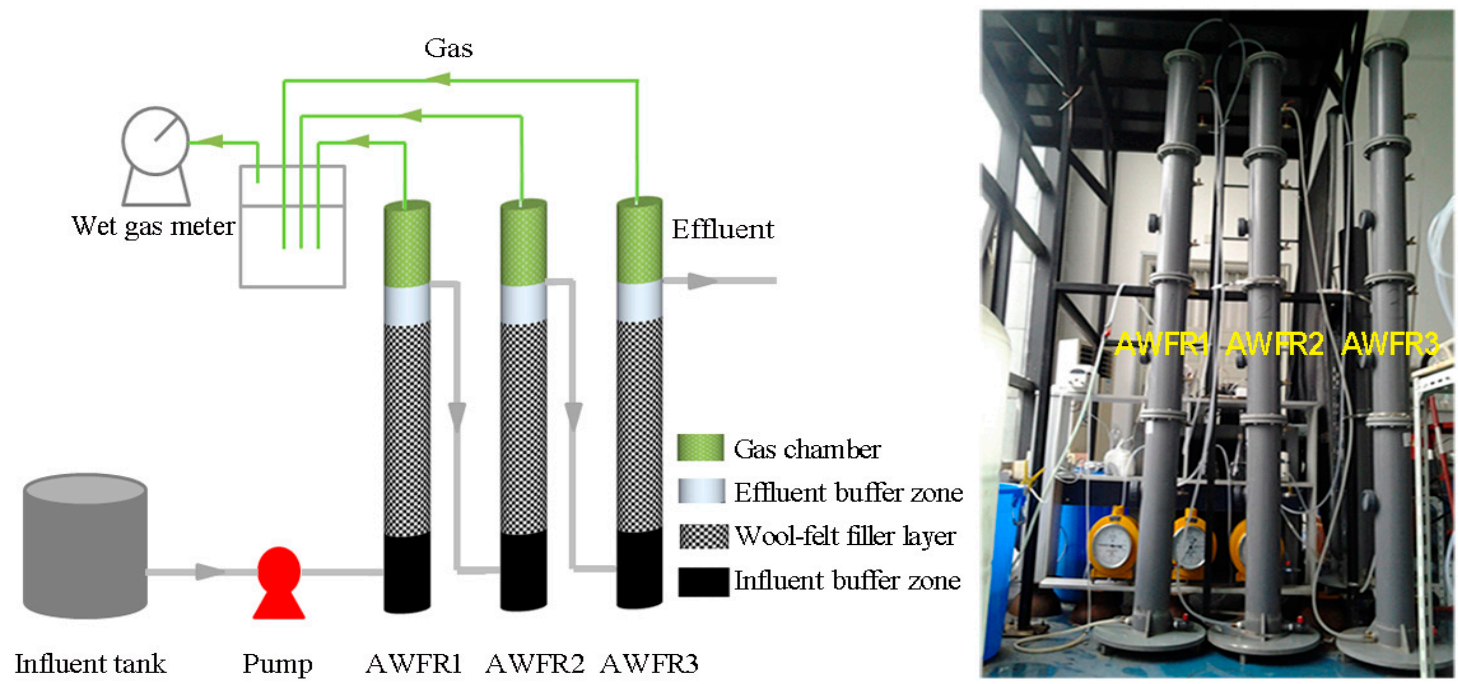

Figure 1. Schematic diagram and photo of the anaerobic wool-felt filter reactor (AWFR).

Table 1. The main operating conditions for the anaerobic wool-felt filter reactor (AWFR) system during the five operation stages.

\begin{tabular}{|c|c|c|c|c|c|c|}
\hline Stage & $\begin{array}{l}\text { Phase } \\
\text { (Days) }\end{array}$ & $\begin{array}{l}\text { Duration } \\
\text { (Days) }\end{array}$ & $\begin{array}{c}\text { Hydraulic } \\
\text { Retention Time } \\
\text { (HRT) (Days) }\end{array}$ & $\begin{array}{c}\text { Hydraulic Loading } \\
\text { Rate (HLR) } \\
\left(\mathrm{m}^{3} / \mathrm{m}^{2} / \text { day) }\right.\end{array}$ & $\begin{array}{c}\text { Organic Loading } \\
\text { Rate (OLR) } \\
\text { (mgCOD/L/day) }^{1}\end{array}$ & $\begin{array}{l}\text { Temperature } \\
\left({ }^{\circ} \mathrm{C}\right)^{1}\end{array}$ \\
\hline start-up & $1-30$ & 30 & 3 & 2.2 & $75 \pm 13.6(n=30)$ & $15 \pm 3.4(n=30)$ \\
\hline spring & $31-90$ & 60 & 2 & 4.4 & $143 \pm 28.3(n=60)$ & $21 \pm 3.0(n=60)$ \\
\hline summer & $91-180$ & 90 & 1 & 6.6 & $352 \pm 61.8(n=90)$ & $31 \pm 3.7(n=90)$ \\
\hline autumn & $181-270$ & 90 & 2 & 4.4 & $135 \pm 32.9(n=90)$ & $25 \pm 5.2(n=90)$ \\
\hline winter & $271-364$ & 94 & 3 & 2.2 & $82 \pm 12.9(n=94)$ & $10 \pm 2.2(n=94)$ \\
\hline
\end{tabular}

\subsection{Decentralized Domestic Wastewater and Seed Sludge}

The experimental setup was fed with real decentralized domestic wastewater, which was collected from the dormitories and restaurants of the Southeast University (Wuxi, China). The chemical characteristics of the decentralized domestic wastewater are presented in Table 2. 
Table 2. The chemical characteristics of decentralized domestic wastewater (unit: $\mathrm{mg} / \mathrm{L}$, except for $\mathrm{pH})$.

\begin{tabular}{ccccc}
\hline Parameter & Chemical Oxygen Demand (COD) & Total Phosphorus (TP) & Total Nitrogen (TN) & pH \\
\hline Value $^{1}$ & $284 \pm 69.2$ & $2.8 \pm 0.8$ & $32.2 \pm 7.7$ & $7.1 \pm 0.2$ \\
\hline
\end{tabular}

${ }^{1}$ Values are given as mean \pm standard deviation; number of measurements $(n): n=364$ for COD, TP, TN and $\mathrm{pH}$.

The seeding anaerobic sludge used in this study was obtained from the anaerobic digester of a municipal wastewater treatment plant located in Wuxi, China. Approximately $10 \mathrm{~L}$ anaerobic sludge was inoculated into the wool felt carrier of each reactor before startup of the AWFR system. The initial total suspended solids (TSS) and volatile suspended solids (VSS) of the seeding anaerobic sludge were $28.2 \mathrm{~g} / \mathrm{L}$ and $14.3 \mathrm{~g} / \mathrm{L}$, respectively.

\subsection{Analysis Methods}

\subsubsection{Chemical Analysis}

Chemical oxygen demand (COD), total nitrogen (TN), total phosphorus (TP), total suspended solids (TSS) and volatile suspended solids (VSS) were measured according to the Standard Methods [34]. The concentrations of volatile fatty acids were analyzed using a gas chromatography GC 3900 (Tenghai, Shandong, China) equipped with an SE-30 capillary column $(30 \mathrm{~m} \times 0.32 \mathrm{~mm} \times 0.25 \mu \mathrm{m})$ and a flame ionization detector. The operation temperatures of the injector port, column oven and detector were 200,120 and $230^{\circ} \mathrm{C}$, respectively. Nitrogen gas was used as the carrier gas at a flow rate of $40 \mathrm{~mL} / \mathrm{min}$. The biogas production was measured by using an LML-1 wet gas meter (Changchun Automobile Filter Co., Ltd., Changchun, China). The biogas composition was determined using a gas chromatography GC 2001 (Tenghai, Shandong, China) equipped with a thermal conductivity detector and a $4 \mathrm{~m} \times 3 \mathrm{~mm}$ inside diameter stainless-steel column packed with TDX-01 (80/100 mesh). The operation temperature of the injector port, column oven and detector were 150, 150 and $180^{\circ} \mathrm{C}$, respectively. Argon gas was used as the carrier gas at a flow rate of $25 \mathrm{~mL} / \mathrm{min}$. The $\mathrm{pH}$ and temperature were measured using a portable YSI-pH 100 meter (YSI Co., Yellow Springs, OH, USA).

\subsubsection{COD Mass Balance Calculation}

The COD mass balance of the AWFR system was conducted during spring, summer, autumn and winter. Seasonal periods were characterized by the following operation HRTs: 2 days (spring period covering Day 31-90), 1 day (summer period covering Day 91-180), 2 days (autumn period covering Day 181-270), and 3 days (winter period covering Day 271-364).

The COD mass balance was calculated using the Equation (1):

$$
\mathrm{COD}_{\text {in }}=\mathrm{COD}_{\mathrm{VFAs}}+\mathrm{COD}_{\mathrm{CH} 4(\mathrm{~g})}+\mathrm{COD}_{\mathrm{CH} 4(\mathrm{~s})}+\mathrm{COD}_{\text {others }}
$$

where: $\mathrm{COD}_{\text {in }}(\mathrm{g} /$ day) represents the average COD concentration of real decentralized domestic wastewater; $\mathrm{COD}_{\text {VFAs }}(\mathrm{g} /$ day) represents the average COD concentration of acetate and propionate in the effluent; $\mathrm{COD}_{\mathrm{CH} 4(\mathrm{~g})}(\mathrm{g} /$ day) represents the average $\mathrm{COD}$ concentration of methane produced in biogas; $\mathrm{COD}_{\mathrm{CH} 4(\mathrm{~s})}(\mathrm{g} /$ day $)$ represents the average $\mathrm{COD}$ concentration of methane dissolved in the effluent; $\mathrm{COD}_{\text {others }}(\mathrm{g} /$ day) represents the organic matter that has been utilized for biomass formation, the complex organic matter that is not biodegradable, COD consumed by sulphate reducing bacteria (SRB), and COD removed and converted to $\mathrm{CO}_{2}$.

Dissolved methane was calculated using Equations (2) and (3) suggested by a previous study [35]:

$$
\begin{gathered}
\mathrm{CH}_{4}(\mathrm{~s})=4 \times \mathrm{K}_{\mathrm{H}} \times \mathrm{P}_{\text {gas }} \times \text { flow }(\mathrm{Q}), \\
\mathrm{K}_{\mathrm{H}}=0.384 \times t+36.44,
\end{gathered}
$$


where $K_{H}(\mathrm{mg} / \mathrm{L} / \mathrm{atm})$ is Henry's constant, $\mathrm{P}_{\text {gas }}(\mathrm{atm})$ is the partial pressure of the gas above the liquid, flow $(\mathrm{Q})\left(\mathrm{L} /\right.$ day) is feed flow and $t\left({ }^{\circ} \mathrm{C}\right)$ is the temperature.

\subsubsection{Scanning Electron Microscopy (SEM)}

Scanning electron microscopy (SEM) was used to investigate the development and structure of the anaerobic biofilm in the system. Representative samples (about $1 \mathrm{~cm}^{2}$ size) were taken from the AWFR system on days 15, 90, 180, 270 and 340 . The samples were firstly fixed with $3 \%(v / v)$ glutaraldehyde in $0.1 \mathrm{M}$ phosphate buffer $\left(\mathrm{pH}\right.$ 6.8) for $4 \mathrm{~h}$ at $4{ }^{\circ} \mathrm{C}$. Then, these samples were washed with $0.1 \mathrm{M}$ phosphate buffer for three times. Subsequently, these samples were dehydrated through graded ethanol $(30 \%$, $50 \%, 70 \%, 90 \%$, and $100 \% v / v, 10 \mathrm{~min}$ for each concentration). After that, the samples were replaced by isoamyl acetate (twice, $10 \mathrm{~min}$ for each time), dried at a critical point and then coated with gold. Finally, these samples were examined via the scanning electron microscope (S-4800, Hitachi, Tokyo, Japan).

\subsubsection{Microbial Community Analysis by Illumina MiSeq Sequencing}

To assess the complete microbial community structures, anaerobic biofilm samples were collected from the AWFR system on days 15, 90, 180, 270 and 340. The total DNA from the anaerobic biofilm samples was extracted using the OMEGA Soil DNA Kit D5625-01 (Omega Bio-Tek, Norcross, GA, USA) based on the manufacturer's protocol. The quality and quantity of the extracted DNA were measured by a Nanodrop 1000 spectrophotometer (NanoDrop Technologies, Wilmington, DE, USA).

For gene libraries construction, the V3-V4 regions of $16 \mathrm{~S}$ rDNA genes were PCR-amplified using BAC319F/806R (5'-ACTCCTACGGGAGGCAGCAG-3' / $5^{\prime}$-GGACTACHVGGGTWTCTAAT-3') and ARC349F/806R (5'-GYGCASCAGKCGMGAAW-3'/5'-GGACTACHVGGGTWTCTAAT-3'), respectively. PCR reactions were conducted in a total volume of $25 \mu \mathrm{L}$ mixture containing $12.5 \mu \mathrm{L}$ Premix Ex TaqTM Hot Start Version (TaKaRa, Dalian, China), $2.5 \mu \mathrm{L}$ of each primer $(1 \mu \mathrm{M}), 25 \mathrm{ng}$ template DNA and $\mathrm{ddH}_{2} \mathrm{O}$. The bacterial PCR amplification was performed under the following conditions: initial denaturing at $98^{\circ} \mathrm{C}$ for $30 \mathrm{~s}, 30$ cycles of denaturing $\left(98^{\circ} \mathrm{C}\right.$ for $30 \mathrm{~s}$ ), annealing $\left(56{ }^{\circ} \mathrm{C}\right.$ for $\left.30 \mathrm{~s}\right)$, and elongation $\left(72{ }^{\circ} \mathrm{C}\right.$ for $45 \mathrm{~s}$ ), and a final extension step at $72{ }^{\circ} \mathrm{C}$ for $10 \mathrm{~min}$. Archaeal community PCR amplification condition was similar to the bacterial community except that the cycle's number was 35 . The PCR products were confirmed by $2 \%$ agarose gel electrophoresis and purified using the AxyPrepDNA Gel Extraction Kit (Axygen, Union City, CA, USA) following the manufacturer's protocol. Finally, the purified amplicons were pooled in equimolar and paired-end sequenced using the Illumina MiSeq platform (Illumina Inc., San Diego, CA, USA).

After sequencing, the raw sequences were filtered for quality, trimmed and processed based on the Mothur (version 1.30.1, http:/ / www.mothur.org) analytic pipeline. Briefly, the adapters, barcodes and primers were trimmed. The sequence reads containing ambiguous base calls, with homopolymers $>6 \mathrm{bp}$ and shorter than $200 \mathrm{bp}$ were removed. Chimeras detected by UCHIME (version 4.2.40, http://drive5. $\mathrm{com} /$ usearch/manual/uchime_algo.html) were filtered out. The resulting high quality sequences were clustered into operation taxonomic units (OTU) at 97\% similarity level by Mothur. Representative sequences selected for each OTU were assigned taxonomy using a Ribosomal Database Project (RDP) classifier with a confidence threshold of $80 \%$. The raw sequencing data were deposited to the National Center for Biotechnology Information (NCBI) Short Read Archive (Accession number: SRP101990).

\section{Results and Discussion}

\subsection{Bioreactor Performance}

\subsubsection{COD Removal}

To evaluate the performance of the AWFR system, the seasonal COD removal efficiencies were investigated at different HRTs for 364 days. During the whole operation period, the influent COD 
concentration ranged from approximately 157 to $469 \mathrm{mg} / \mathrm{L}$ (Figure 2). At the beginning of the start-up period (days 1-30), the AWFR was operated in the temperatures ranged from $8{ }^{\circ} \mathrm{C}$ to $17^{\circ} \mathrm{C}$, with an HRT of three days. The COD removal efficiency fluctuated in the range of $24.6-51.8 \%$. Based on the COD removal efficiency in the start-up period, we concluded that microbial community adapted to the operation conditions and the AWFR was successfully initiated. The COD removal efficiency increased gradually in spring (days 31-90), thus resulting in an average COD removal efficiency of $61 \pm 7.9 \%(n=60)$ at an HRT of two days, with average temperature variations of $21 \pm 3.0^{\circ} \mathrm{C}$ $(n=60)$. COD removal efficiency can improve with temperature. Thus, the HRT was adjusted to one day when the average temperature increased to $31 \pm 3.7^{\circ} \mathrm{C}(n=90)$ in summer (days $\left.91-180\right)$. Despite shortening the HRT, following temperature increase, the average effluent COD concentration decreased to $82.5 \mathrm{mg} / \mathrm{L}$, and the average COD removal efficiency increased to $76 \pm 7.2 \%(n=90)$. The change in COD removal efficiency might be due to higher activities of microbial communities in summer. In order to keep COD removal efficiency above 50\%, the HRT was adjusted from two days (autumn) to three days (winter). Even though the OLR decreased from $135 \pm 32.9 \mathrm{mgCOD} / \mathrm{L} /$ day $(n=90)$ in autumn to $82 \pm 12.9 \mathrm{mgCOD} / \mathrm{L} /$ day $(n=94)$ in winter, the COD removal efficiency still decreased from $57 \pm 9.4 \%$ (autumn, average temperature $25 \pm 5.2{ }^{\circ} \mathrm{C}, n=90$ ) to $52 \pm 5.9 \%$ (winter, average temperature $\left.10 \pm 2.2^{\circ} \mathrm{C}, n=94\right)$. These findings indicated that the temperature played an important role in the AWFR system operation. Low temperature might increase the wastewater viscosity, slow down the rate of biological reaction, and decrease COD removal efficiency. Compared to the previous study with elastic fiber carriers in two-stage anaerobic filter for domestic wastewater treatment [12], the COD removal efficiency in this study was better, which may be because the wool felt carrier enhanced the agglomeration of the microbial community in the AWFR system. Overall, the performance of the AWFR system was relatively stable and the COD removal efficiency was higher in summer than in winter. To achieve better performance of the AWFR system at the temperature ranging from $8{ }^{\circ} \mathrm{C}$ to $35^{\circ} \mathrm{C}$, an $\mathrm{HRT}$ of three days is recommended.

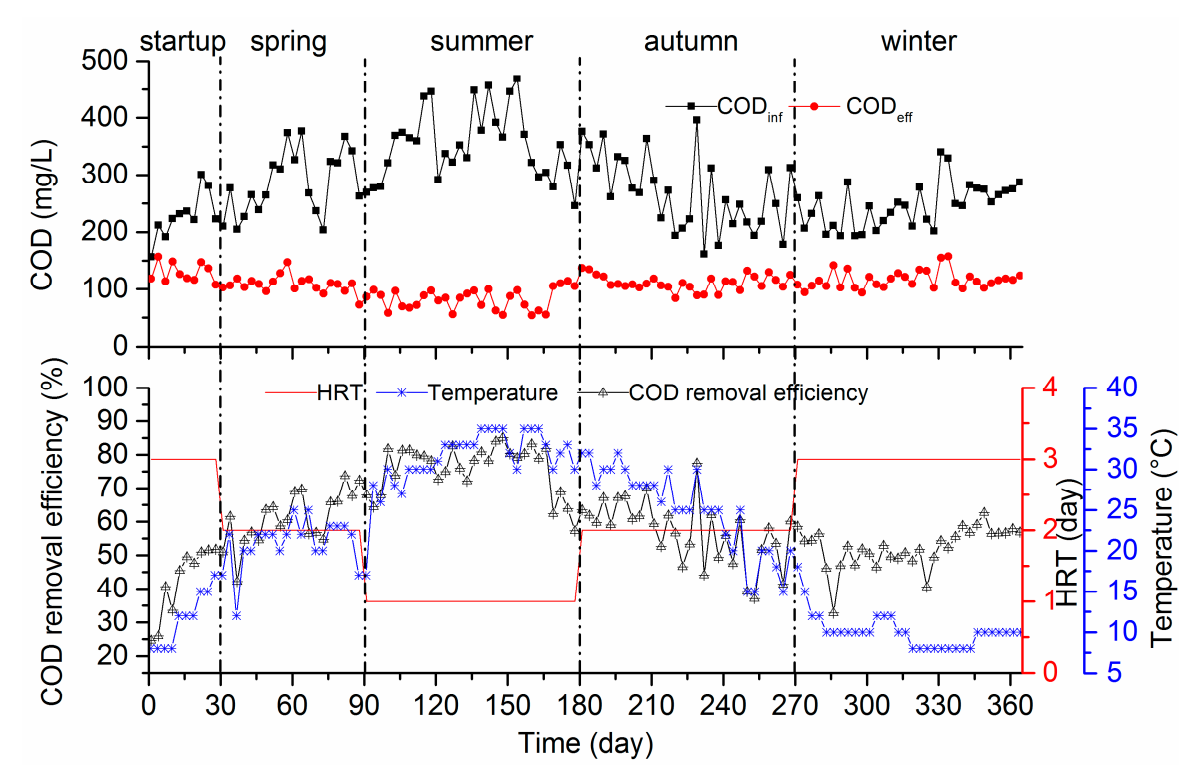

Figure 2. Influent and effluent concentrations of chemical oxygen demand (COD) and COD removal efficiency.

\subsubsection{VFA Accumulation and Biogas Production}

Since volatile fatty acids (VFA) is an important performance indicator of the anaerobic system, the variation of VFAs with respect to seasonal temperature variations was studied in the AWFR system. It was observed clearly that acetate and propionate were the main VFAs in the effluent as shown in Figure 3, indicating that organic matter was degraded to VFAs by both hydrolytic and 
acidogenic bacteria. However, no butyrate and valerate were detected, which might be due to their low concentrations below the detection threshold. During spring (days 31-90), the average effluent concentrations of acetate and propionate were $44.5 \pm 8.2 \mathrm{mg} / \mathrm{L}(n=60)$ and $3.8 \pm 1.6 \mathrm{mg} / \mathrm{L}(n=60)$, respectively. With the average temperature increasing to $31 \pm 3.7^{\circ} \mathrm{C}(n=90)$ in summer (days $\left.91-180\right)$, the average effluent concentrations of acetate and propionate drastically dropped to $30.1 \pm 5.0 \mathrm{mg} / \mathrm{L}$ $(n=90)$ and $2.6 \pm 0.7 \mathrm{mg} / \mathrm{L}(n=90)$, respectively. Nevertheless, the concentrations of acetate and propionate increased from $45.6 \pm 15.6 \mathrm{mg} / \mathrm{L}(n=90)$ and $6.3 \pm 2.6 \mathrm{mg} / \mathrm{L}(n=90)$ to $62.1 \pm 8.5 \mathrm{mg} / \mathrm{L}$ $(n=94)$ and $6.3 \pm 3.2 \mathrm{mg} / \mathrm{L}(n=94)$ in winter. Similar results were also observed with AFBR to treat domestic wastewater in winter [36]. The effluent concentrations of both acetate and propionate were much lower than those in winter even though the OLR in summer $(352 \pm 61.8 \mathrm{mgCOD} / \mathrm{L} /$ day, $n=90)$ was higher. This coincided with higher COD removal efficiency in summer than in winter, indicating that the conversion of VFAs to biogas was higher in summer than in winter because of high activities of the microbial community, especially for acetoclastic methanogens. Based on these findings, we further confirmed that the seasonal temperature variations affected the anaerobic metabolism of decentralized wastewater.

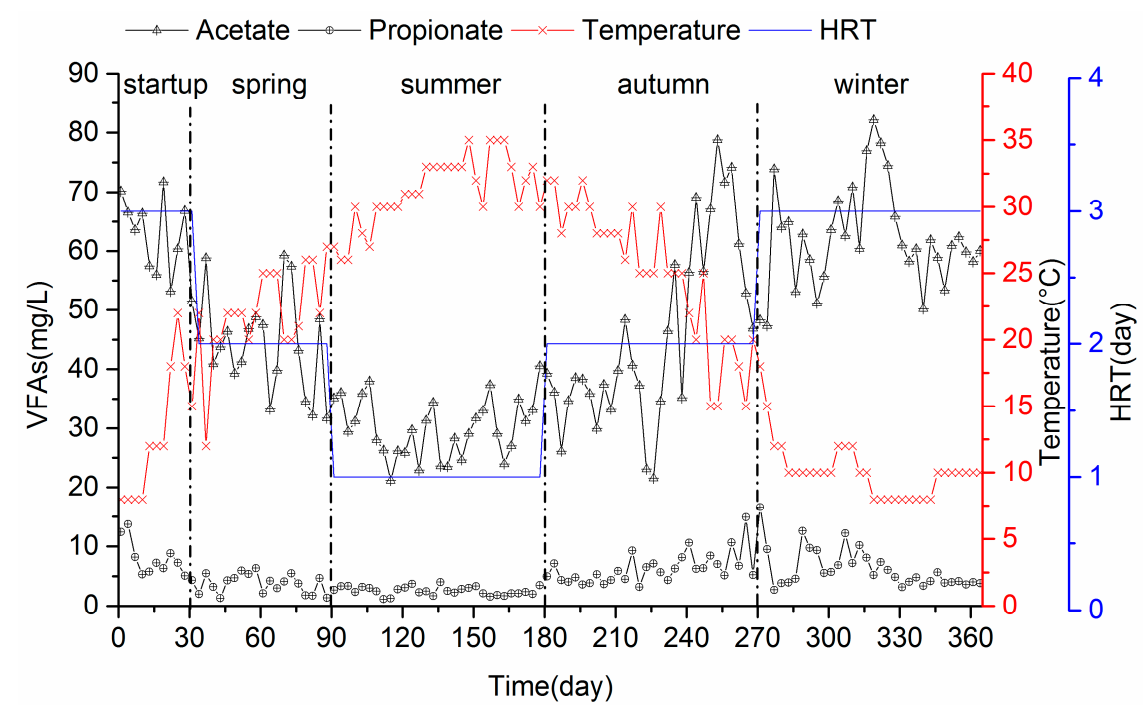

Figure 3. Volatile fatty acids (VFAs) production in the AWFR system during the whole operation.

The daily biogas production is shown in Figure 4. The daily biogas production in the start-up period was low, but after the formation of the stable anaerobic biofilm, it gradually increased with temperature increase, even though the HRT was reduced. The maximum daily biogas production of $10.7 \mathrm{~L} /$ day was achieved in summer, when the HRT was one day. This result corresponded well with a high reduction of COD concentration in effluent and a high COD removal efficiency during that period. However, the biogas production decreased with temperature decrease in winter, while acetate and propionate were accumulated. The lower biogas production in winter might be explained by poor degradation of organic matter and higher solubility of biogas at a lower temperature. 


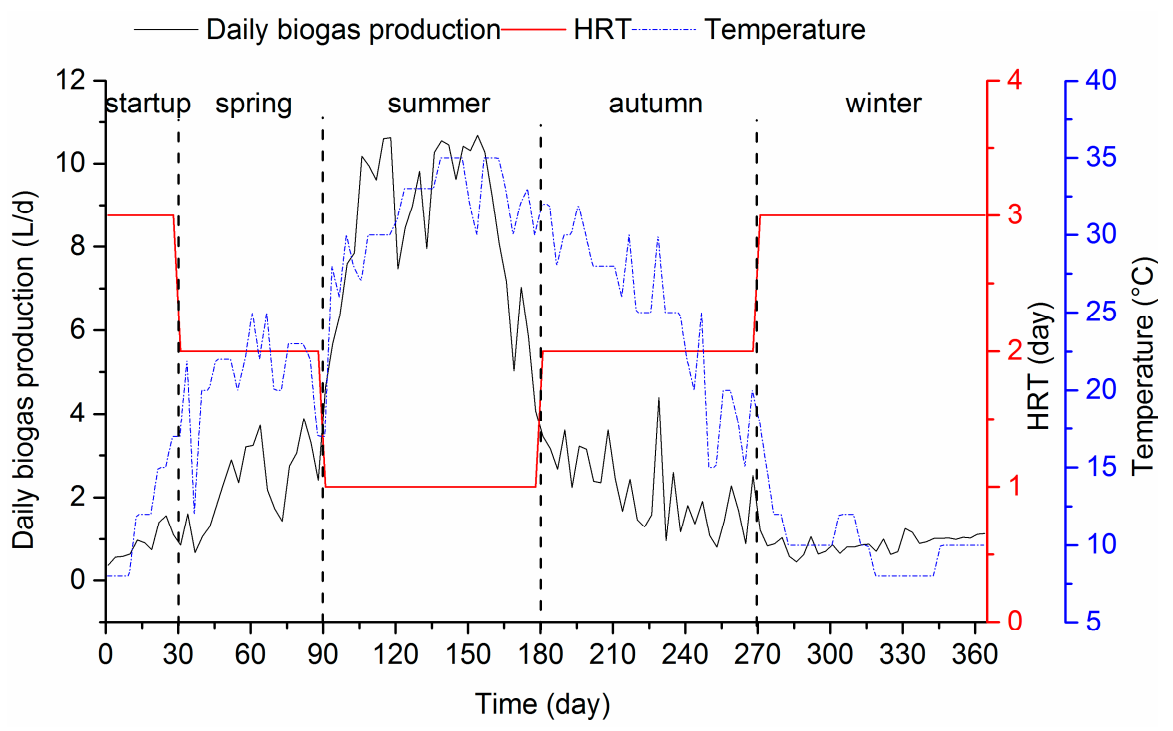

Figure 4. Biogas production in the system during the whole operation.

\subsection{COD Mass Balance}

Based on Equations (1)-(3), a COD mass balance was used to assess the bioconversion process of organic matter during spring, summer, autumn and winter (Figure 5). Approximately 43.5-52.5\% of influent COD was converted to methane (including gaseous methane and dissolved methane). Similar COD conversions were reported for an anaerobic filter treating on-site domestic wastewater [37]. In addition, $10.2-31.0 \%$ of influent COD was converted to VFAs, while $25.5-37.3 \%$ of influent COD was transformed to biomass, $\mathrm{CO}_{2}$ and non-biodegradable organic matters. During the spring, about $28.3 \%$ of influent COD was converted to gaseous methane and $18.7 \%$ of influent COD was accounted for VFAs. With an increase of temperature in summer, more organic matter was converted to gaseous methane (41.1\% of influent COD) than VFAs (10.2\% of influent COD). In contrast, more VFAs were accumulated in winter. Meanwhile, the results demonstrated that dissolved methane represented about $17.7 \%, 11.4 \%, 16.4 \%$, and $23.7 \%$ of COD during spring, summer, autumn, and winter, respectively, indicating that more methane dissolved in effluent with a decrease of temperatures. As a potential energy resource, future studies should focus on the recovery of dissolved methane in the AWFR system to avoid the loss of dissolved methane.

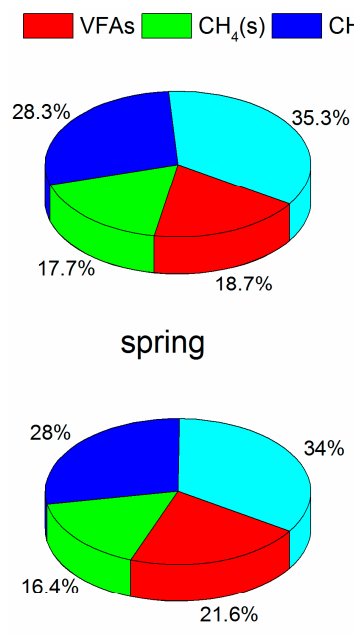

autumn
$\mathrm{CH}_{4}(\mathrm{~g}) \square \mathrm{COD}_{\text {others }}$

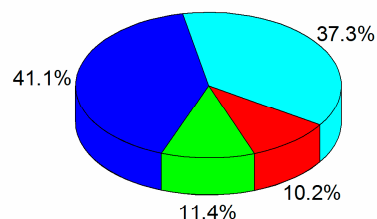

summer

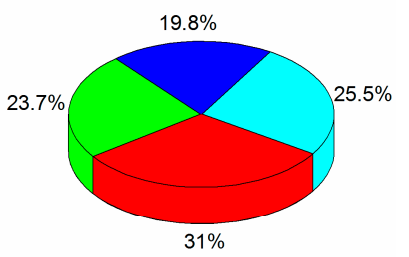

winter

Figure 5. COD balance in different seasons. 


\subsection{Nutrient Removal}

Nitrogen and phosphorous are two important nutrients for agricultural and landscaping reuse. The influent and effluent concentrations of TN and TP were monitored throughout the whole operation period. As shown in Figure 6a,b, the influent concentration of TN fluctuated from 19.6 to $54.2 \mathrm{mg} / \mathrm{L}$ throughout the operation period. In spring, with the temperature of $21 \pm 3.0^{\circ} \mathrm{C}(n=60)$, the TN concentration in the effluent of the AWFR system was $30.2 \pm 5.9 \mathrm{mg} / \mathrm{L}(n=60)$, corresponding to a $15.7 \pm 2.5 \%(n=60) \mathrm{TN}$ removal efficiency at an HRT of two days. When the temperature increased to $31 \pm 3.7^{\circ} \mathrm{C}(n=90)$ in summer, the TN removal efficiency slightly increased to $19.0 \pm 2.7 \%(n=90)$ at an HRT of one day. Despite an HRT increase from one day in summer to three days in winter, the average TN removal efficiency decreased to $12.9 \pm 2.8 \%(n=94)$. Overall, the TN removal was low in this study because TN was probably removed by microbial assimilation only, and not via a nitrification-denitrification pathway. Meanwhile, a similar trend was observed for TP removal (Figure $6 c, d) .25 .0 \pm 3.5 \%(n=90)$ of TP was removed in summer at an HRT of one day, corresponding to an average effluent TP concentration of $2.2 \pm 0.48 \mathrm{mg} / \mathrm{L}(n=90)$. With the decrease of temperature from summer to winter, TP removal efficiency in winter was $16.1 \pm 4.4 \%(n=94)$ at an HRT of three days, which corresponded to an average TP concentration in the effluent of $2.0 \pm 0.44 \mathrm{mg} / \mathrm{L}$ ( $n=94)$. Most of the TN and TP remained in the effluent of the AWFR system. Therefore, future studies should focus on the ecological post-treatment of the AWFR system.
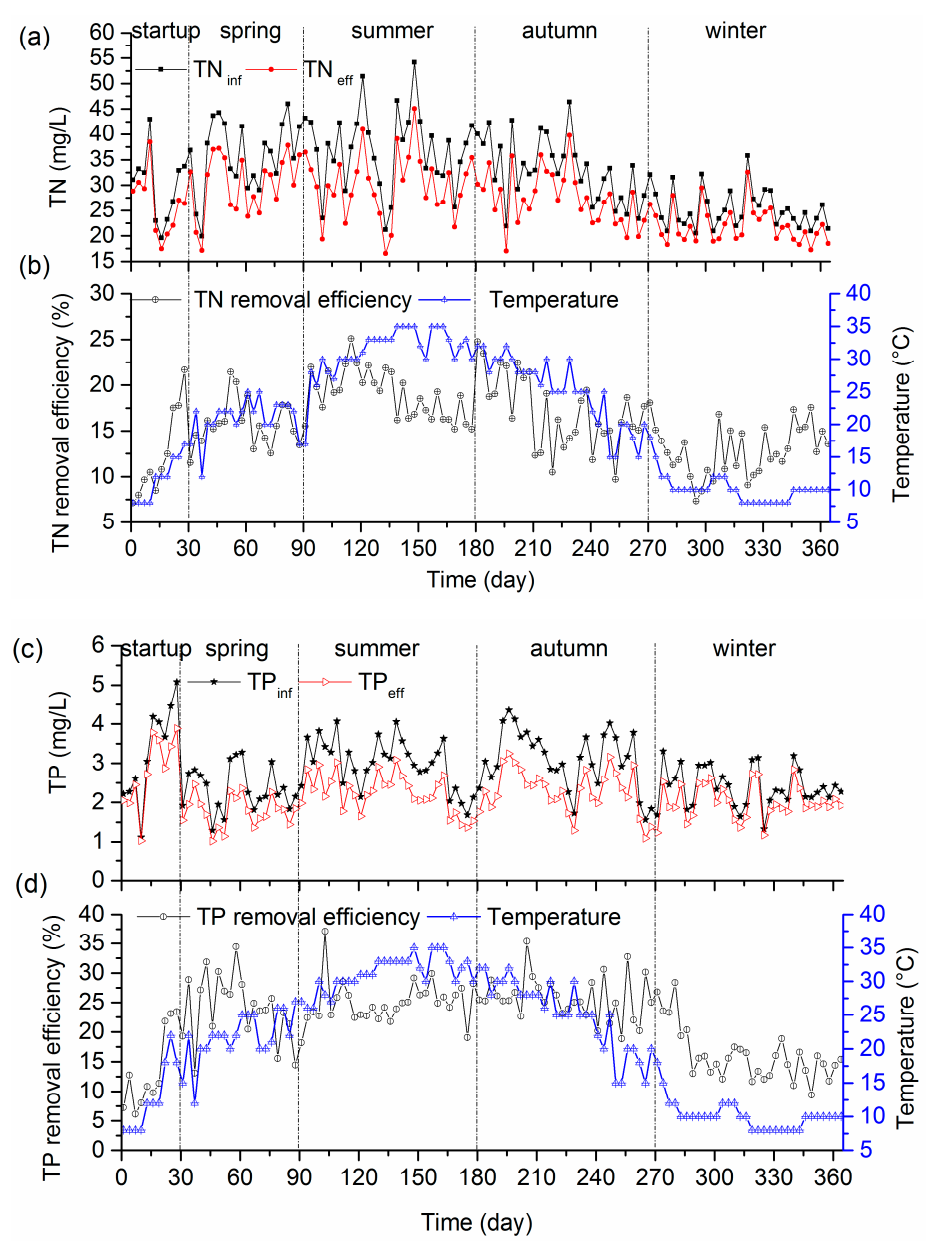

Figure 6. Total nitrogen (TN) $(\mathbf{a}, \mathbf{b})$ and total phosphorus (TP) (c,d) concentration in influent, effluent and the removal efficiency throughout the operation period. 


\subsection{Morphology and Structure of Anaerobic Biofilm Development}

The biofilm in an anaerobic bioreactor comprises a complex microbial community. To observe the morphology and structures of the anaerobic biofilm, representative anaerobic biofilm samples $(15,90,180$, 270 and 340 days) were taken from the system for SEM analysis. Images of SEM revealed that the wool felt carrier had a highly porous and rough surface structure that played important roles in the anaerobic biofilm formation (Figure 7). Various types of microbes initially began to develop on the surface of the wool felt carrier primarily by Van der Waals and electrostatic forces (Figure 7a) [38,39]. From the anaerobic biofilm, cocci, bacillus, and filamentous bacteria were observed on the wool felt carrier. The anaerobic biofilm gradually became thicker (Figure $7 \mathrm{c}, \mathrm{e}, \mathrm{g}$ ). A predominance of bacillus and filamentous bacteria deep into the biofilm matrix could be noticed. In addition, the filament-shaped Methanosaeta-like structures, long rod-shaped Methanobacterium-like structures, and Methanolinea-like structures were observed by SEM (Figure $7 \mathrm{~b}, \mathrm{~d}, \mathrm{f}, \mathrm{h}, \mathrm{j})$, which were also observed in previous studies [31,40]. SEM observations were further confirmed by Illumina MiSeq sequencing analysis.

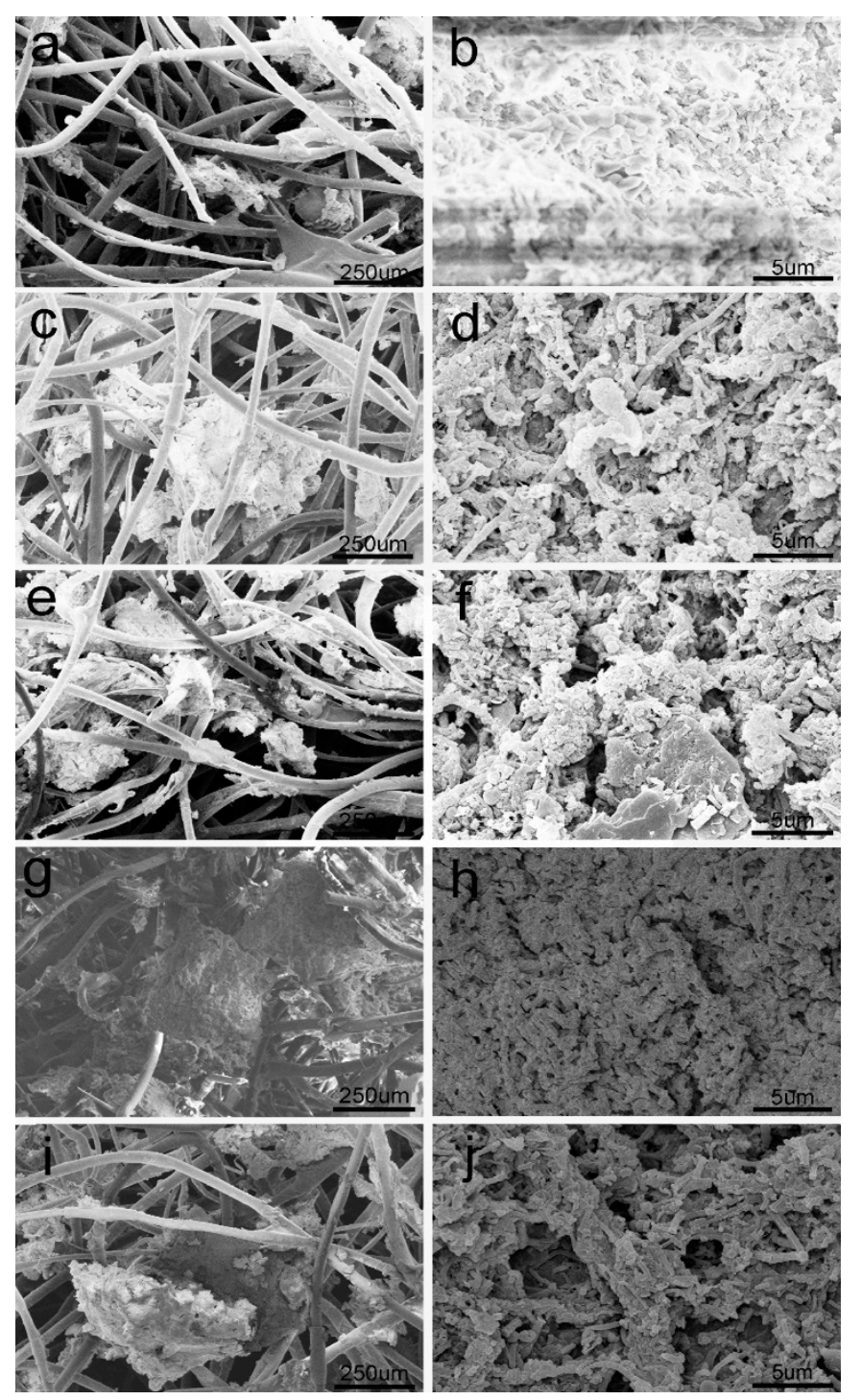

Figure 7. SEM of biofilm on the wool felt in the reactor: $(\mathbf{a}, \mathbf{b})$ : start-up on day $15 ;(\mathbf{c}, \mathbf{d})$ : spring on day 90; (e,f): summer on day 180; $(\mathbf{g}, \mathbf{h})$ : autumn on day $270 ;(\mathbf{i}, \mathbf{j})$ : winter on day 340. 


\subsection{Shifts in Microbial Community Structures with Seasonal Temperature}

High COD removal and biogas production were achieved by the AWFR system in summer, but not in winter. To better elucidate the changes of the microbial community and explore the COD removal mechanism during the whole operation period, the composition and structures of the microbial community were analyzed. Biofilm samples on days 15, 90, 180, 270 and 340, which represented five different periods of the AWFR, were chosen for high-throughput sequencing by the Illumina MiSeq platform.

The archaeal community had a lower diversity and most of the archaeal sequences were assigned to the three main orders Methanosarcinales, Methanobacteriales and Methanomicrobiales throughout the operation period (Figure 8a). These orders occupied $92.8-96.5 \%$ of the total community and were closely related to acetotrophic and hydrogenotrophic methanogen. During the start-up period, the predominant orders Methanosarcinales, Methanobacteriales and Methanomicrobiales accounted for $49.3 \%, 21.4 \%$, and $22.2 \%$, respectively, of the total community. However, the relative abundance of the order Methanosarcinales (34.3\%) decreased in spring, whereas the relative abundances of the orders Methanobacteriales (35.0\%) and Methanomicrobiales (26.0\%) increased. In contrast, the order Methanosarcinales showed an increase in abundance during summer, but a reduction in abundance in winter. The relative abundances of the orders Methanobacteriales and Methanomicrobiales significantly decreased in summer but largely increased in winter.

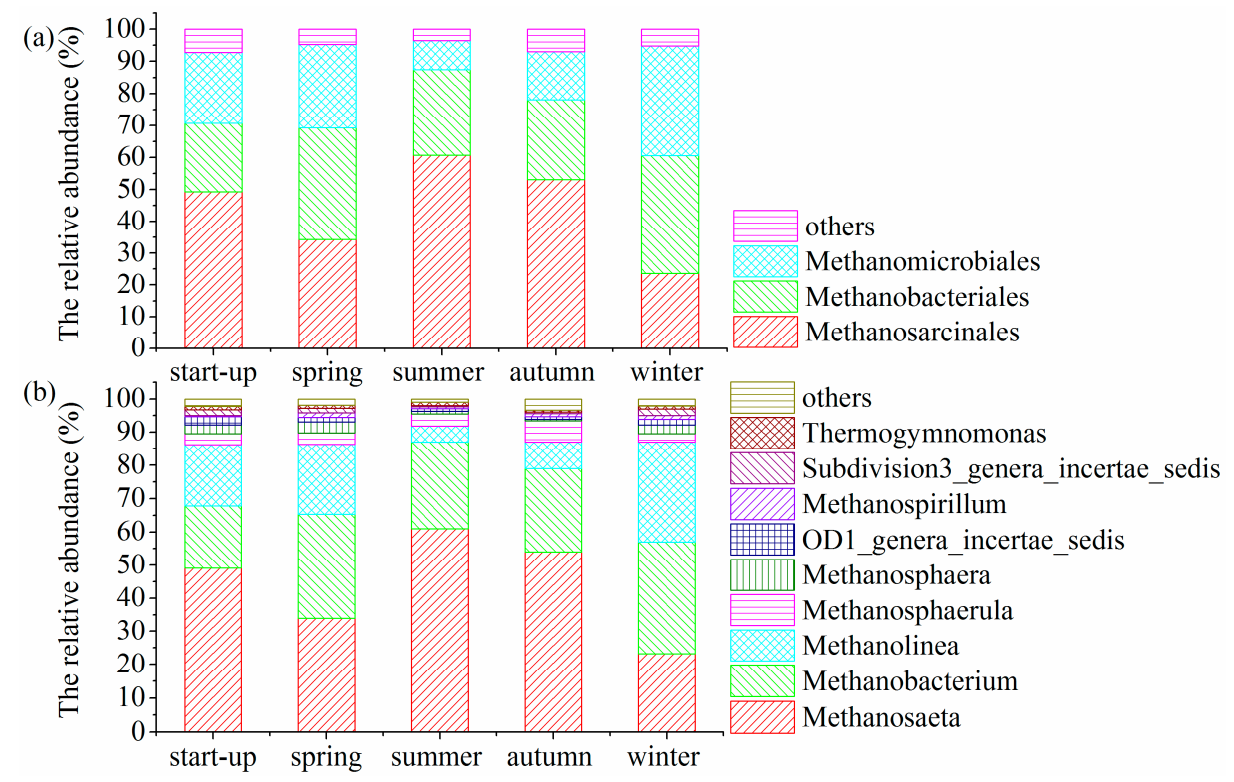

Figure 8. Archaeal community shifts at (a) order and (b) genus level.

To further validate the function of archaeal community, the microbial distribution at genus level was shown in Figure 8b. The results demonstrated that Methanosaeta, Methanobacterium and Methanolinea were the predominant genera throughout the operation period. Among these genera, Methanosaeta was affiliated with acetoclastic methanogen and the remaining genera Methanobacterium and Methanolinea were affiliated with hydrogenotrophic methanogens. Methanosaeta affiliated with the order Methanosarcinales had a high relative abundance (49.2\%) in the start-up period, whereas the relative abundances of the genera Methanobacterium and Methanolinea were $18.7 \%$ and $18.3 \%$, respectively. During summer, the genus Methanosaeta (61.0\%) was the most abundant followed by the genera Methanobacterium (26.1\%) and Methanolinea $(4.8 \%)$. These findings indicated that acetoclastic methanogenesis was the main pathway, with some contribution from the hydrogenotrophic methanogens. These genera may have helped the AWFR system to maintain low VFA level, leading to relatively better COD removal efficiency and higher biogas production in summer. These results were 
in accordance with that in a previous study, achieving higher COD efficiency and biogas production in summer in a UASB treating domestic wastewater [8]. Nevertheless, during the winter period, the hydrogenotrophic genus Methanobacterium (33.8\%) was the most dominant species followed by the hydrogenotrophic genus Methanolinea (29.9\%) and the acetoclastic genus Methanosaeta $(23.2 \%)$. Furthermore, other less abundant hydrogenotrophic genera were also detected in winter, including the genera Methanospirllum, Methanosphaerula and Methanosphaera, which are capable of using $\mathrm{H}_{2} / \mathrm{CO}_{2}$ to produce methane. Hydrogenotrophic genera $(>63.7 \%)$ made up a large portion of the archaeal community in winter. These findings were in line with the previous observations of methanogen population shifts to favor hydrogen utilization under low temperatures [25,41-43]. It might be explained that lower temperature in winter affected the microbial membrane fluidity and inhibited the utilization of acetate than $\mathrm{H}_{2}$ [44]. Although the relative abundance of the hydrogenotrophic genera was much higher than the acetoclastic genera in winter, COD removal and biogas production in winter were lower compared with in summer. The low temperature in winter may affect more the $\mathrm{H}_{2} / \mathrm{CO}_{2}$ methanogenesis than $\mathrm{H}_{2} / \mathrm{CO}_{2}$-dependent acetate production, and decrease the conversion rate of $\mathrm{H}_{2} / \mathrm{CO}_{2}$ to methane and increase the acetate accumulation [41,44].

In contrast to the archaeal community, the bacterial community in the AWFR system showed high diversity: 33 taxonomic categories at phyla level were identified (Table S1). This result was consistent with the previous studies [45-47]. This high diversity might suggest that a variety of bacterial communities participated in multiple metabolic pathways of organic matter degradation under seasonal temperature variation. The predominant bacteria in the AWFR system during the whole operation period were grouped into four phyla affiliated with Firmicutes, Proteobacteria, Bacteroidetes, and Chloroflexi, which occupied $89.3 \pm 4.08 \%$ of the total phyla (Figure 9). These dominant phyla were also detected in the full-scale biogas digesters [47,48]. During the start-up period, the predominant microorganisms in the AWFR system belonged to the phylum Proteobacteria, Firmicutes, Bacteroidetes and Chloroflexi, with a relative abundance of $33.01 \%, 22.19 \%, 19.94 \%$ and $11.29 \%$, respectively. With an increase of temperatures from spring to summer, the bacterial community structures remarkably changed. The abundance of the phylum Firmicutes increased from $37.26 \%$ to $64.97 \%$, whereas the relative abundances of the phyla Proteobacteria, Bacteroidetes, and Chloroflexi decreased from $28.02 \%$ to $14.96 \%, 16.03 \%$ to $10.06 \%$, and $6.00 \%$ to $3.87 \%$, respectively. Interestingly, with a decrease of seasonal temperatures from summer to winter, the relative abundance of Firmicutes drastically decreased from $64.97 \%$ to $29.39 \%$. In contrast, Proteobacteria, and Bacteroidetes obviously increased from $14.96 \%$ to $31.50 \%$ and $10.06 \%$ to $20.66 \%$, respectively. Each phylum in our system likely possessed different tolerance and adaptation mechanisms to seasonal temperature variations. This was consistent with previous studies, stressing that temperature was the vital factor affecting the structures of the bacterial community in anaerobic digestion [48].

To gain further insight into the bacterial community structure in the AWFR system, some main bacteria at class level are shown in Figure 9b. During the start-up period, the dominant class was Gammaproteobacteria affiliated with the phylum Proteobacteria, with a relative abundance of $13.67 \%$, followed by Bacteroidia, Clostridia, Anaerolineae and Bacilli, with a relative abundance of $12.87 \%, 11.88 \%$, $10.96 \%$ and $9.89 \%$, respectively. Among these predominant classes, Bacteroidia and Clostridia played significant roles in hydrolysis metabolism [47-49]. Gammaproteobacteria was the most representative class during the start-up period, which was also the main contributor to the phylum Proteobacteria. However, with an increased temperature during the summer period, Bacilli affiliated with the phylum Firmicutes was the most representative class, with a relative abundance of $57.17 \%$, while the relative abundances of Bacteroidia and Clostridia were $6.61 \%$ and $7.43 \%$, respectively. These results probably indicate that seasonal temperature in summer benefited the growth of Bacilli bacteria. Bacteroidales affiliated with the class Bacteroidia had been identified as hydrolyser and fermenter that participated in the conversation of cellulose and polysaccharide into VFAs [49]. Clostridiales affiliated with the class Clostridia was correlated with methane production, due to their diverse metabolism that utilized polysaccharide fermentation to produce VFAs for methanogenesis $[47,48]$. It was interesting to note 
that the class Bacteroidales was much more abundant in winter $(12.45 \%)$ than in summer $(6.61 \%)$, corresponding to an increase of VFAs in the winter. These results also corresponded with the decrease of COD removal efficiency and biogas production in the winter. Furthermore, the class Deltaproteobacteria was much less abundant in summer $(1.94 \%)$ than in winter $(7.81 \%)$. A similar tendency was shown by the class Alphaproteobacteria ( $4.92 \%$ in summer, and $9.57 \%$ in winter) and Betaproteobacteria $(3.84 \%$ in summer, and $7.63 \%$ in winter).

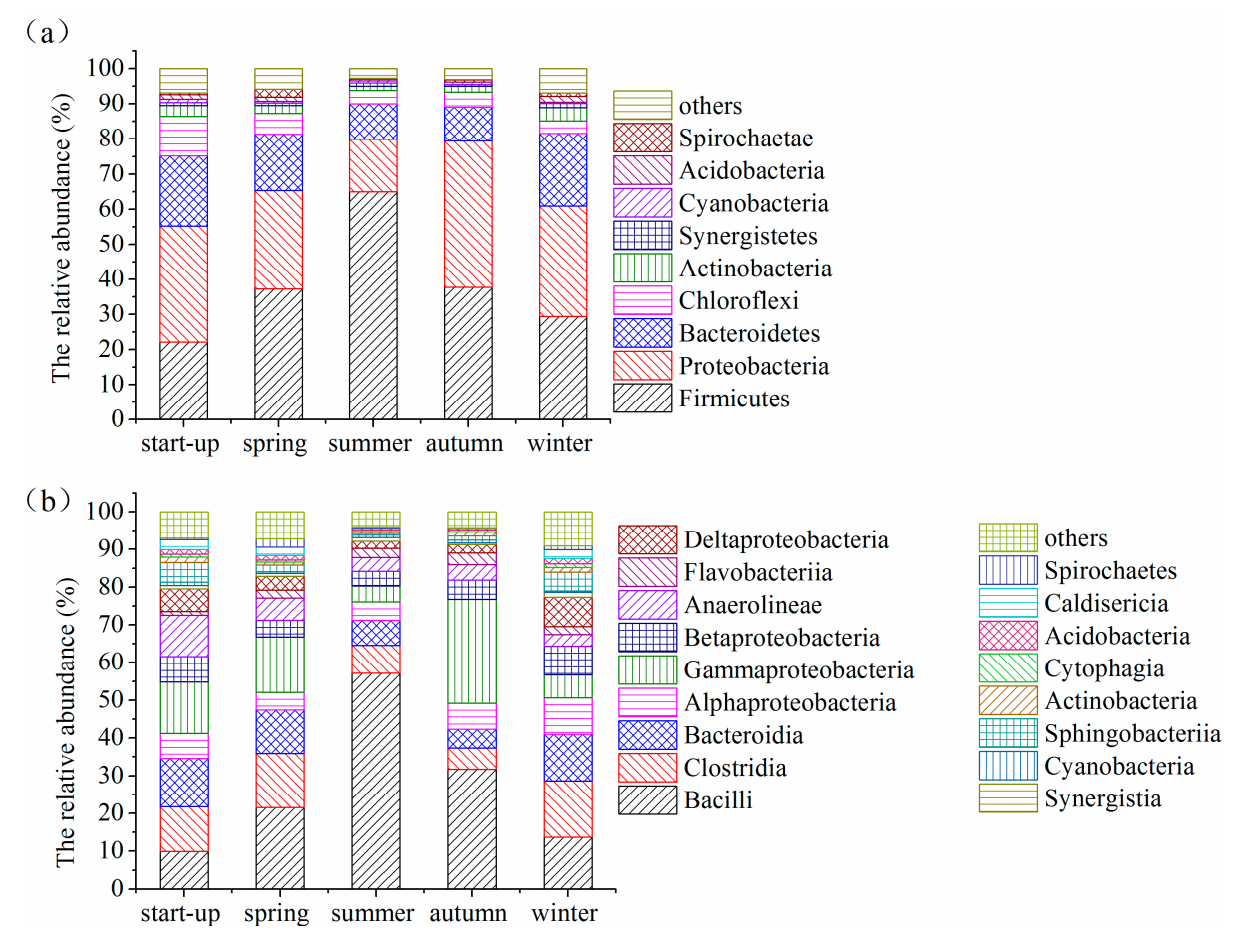

Figure 9. Bacterial community shifts at (a) phylum and (b) class level.

In order to better evaluate the structures of bacterial communities, the top 10 dominant genera in different periods of the system are presented in Figure 10. Among these genera, although the relative abundance of the bacteria at genus level differed depending on the operation conditions, it appeared that Bacillus was the most abundant genus throughout the whole operation period. Bacillus has been reported to possess the abilities of degrading various organic compounds [50-53]. The genus Pseudomonas, with a chemolithoautotrophic and heterotrophic functionality, has been reported to play an important role in organic compound degradation [54,55]. The presence of Bacillus and Pseudomonas in summer might be responsible for the degradation of organic matters by the AWFR system. This finding was consistent with the high COD removal efficiency and low effluent concentration of COD in summer. In addition, VadinBC27_wastewater-sludge_group was also observed throughout the operation period. It might be participating in the degradation of amino acids and some refractory organic matters [56-58]. The genus Smithella, which could degrade propionate to acetate [42,59], was dominant in start-up (3.13\%) and winter (3.5\%), and this was probably one of the reasons of acetate accumulation. The genus Acinetobacter was observed in autumn and winter, and was probably involved in the oxidation of organic matter or sulfides [13,60]. 

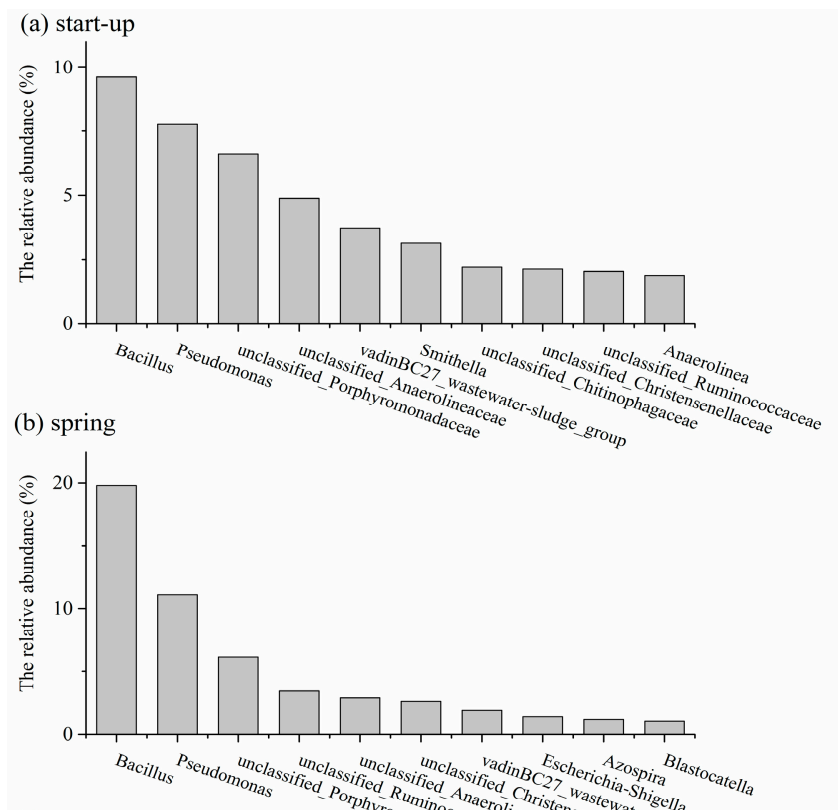

(c) summer $\quad{ }^{2}$
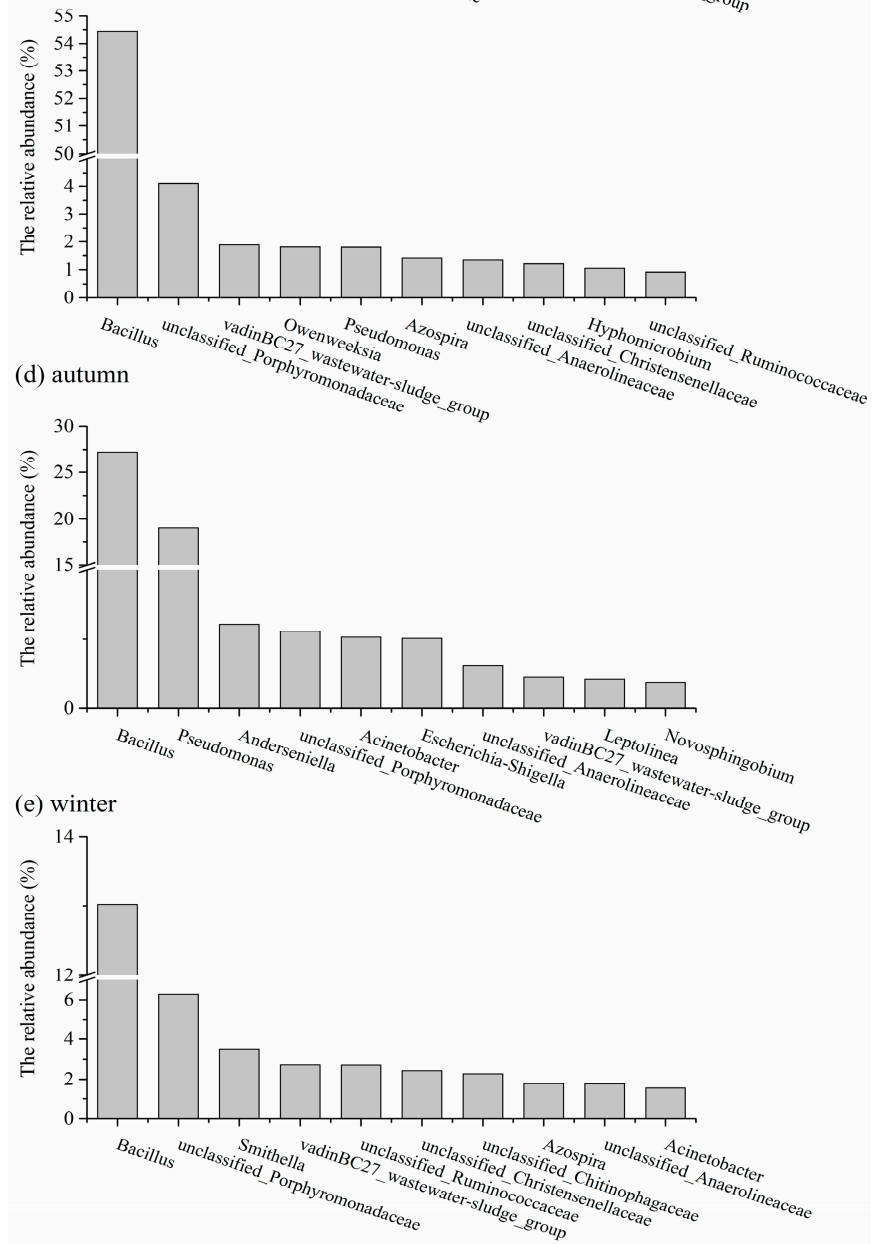

Figure 10. The top 10 bacterial genera during (a) start-up; (b) spring; (c) summer; (d) autumn; (e) winter period. 


\section{Conclusions}

This study assesses the performance of the three-stage AWFR system for the treatment of decentralized domestic wastewater under seasonal variation of temperature. The COD removal efficiency changed with temperature: the average COD removal efficiency in summer and winter were $76 \pm 7.2 \%$ (1-day HRT) and $52 \pm 5.9 \%$ (3-day HRT), respectively. Although COD removal was lower in winter, approximately $43.5 \%$ of the influent COD was still converted to methane during that period. Miseq sequencing results suggested that seasonal temperature had a strong impact on the microbial community composition. The genera Methanosaeta, Methanobacterium, and Methanolinea were the predominant methanogens, whereas Bacillus was always the most abundant genus, which probably contributed to the fermentation processes throughout the whole operation period. Most of the nutrients, i.e., $\mathrm{N}$ and $\mathrm{P}$, remained in the effluent, which could be treated by wetland or used for irrigation for agriculture. The AWFR system appears to be a sustainable option for the pretreatment of the decentralized domestic wastewater. However, longer HRT needs to be applied during winter.

Supplementary Materials: The following are available online at www.mdpi.com/2076-3417/7/6/605/s1, Table S1: The relative abundance of bacterial community at phylum level.

Acknowledgments: This research was supported by China National Water Pollution Control and Management Technology Major Projects (2012ZX07101-005). The authors would like to thank the editor and the anonymous reviewers for editing and review. We thank Liwei Sun, Ran Yu, Haq Nawaz Abbasi and John Leju Celestino Ladu for useful comments and manuscript polishing.

Author Contributions: Juanhong Li and Xiwu Lu conceived and designed the experiments, analyzed the data, and wrote the paper.

Conflicts of Interest: The authors declare no conflicts of interest.

\section{References}

1. Yu, R.; Wu, Q.; Lu, X. Constructed wetland in a compact rural domestic wastewater treatment system for nutrient removal. Environ. Eng. Sci. 2012, 29, 751-757. [CrossRef]

2. Dong, H.-Y.; Qiang, Z.-M.; Wang, W.-D.; Jin, H. Evaluation of rural wastewater treatment processes in a county of eastern China. J. Environ. Monit. 2012, 14, 1906-1913. [CrossRef] [PubMed]

3. McCarty, P.L.; Bae, J.; Kim, J. Domestic wastewater treatment as a net energy producer-Can this be achieved? Environ. Sci. Technol. 2011, 45, 7100-7106. [CrossRef] [PubMed]

4. Chernicharo, C.; Van Lier, J.; Noyola, A.; Ribeiro, T.B. Anaerobic sewage treatment: State of the art, constraints and challenges. Rev. Environ. Sci. Bio/Technol. 2015, 14, 649-679. [CrossRef]

5. López-López, A.; Albarrán-Rivas, M.G.; Hernández-Mena, L.; León-Becerril, E. An assessment of an anaerobic filter packed with a low-cost material for treating domestic wastewater. Environ. Technol. 2013, 34, 1151-1159. [CrossRef] [PubMed]

6. Smith, A.L.; Skerlos, S.J.; Raskin, L. Membrane biofilm development improves COD removal in anaerobic membrane bioreactor wastewater treatment. Microb. Biotechnol. 2015, 8, 883-894. [CrossRef] [PubMed]

7. Mei, X.; Wang, Z.; Miao, Y.; Wu, Z. Recover energy from domestic wastewater using anaerobic membrane bioreactor: Operating parameters optimization and energy balance analysis. Energy 2016, 98, 146-154. [CrossRef]

8. Bandara, W.M.; Kindaichi, T.; Satoh, H.; Sasakawa, M.; Nakahara, Y.; Takahashi, M.; Okabe, S. Anaerobic treatment of municipal wastewater at ambient temperature: Analysis of archaeal community structure and recovery of dissolved methane. Water Res. 2012, 46, 5756-5764. [CrossRef] [PubMed]

9. Chong, S.; Sen, T.K.; Kayaalp, A.; Ang, H.M. The performance enhancements of upflow anaerobic sludge blanket (UASB) reactors for domestic sludge treatment-a state-of-the-art review. Water Res. 2012, 46, 3434-3470. [CrossRef] [PubMed]

10. Feng, J.; Wang, Y.; Ji, X.; Yuan, D.; Li, H. Performance and bioparticle growth of anaerobic baffled reactor (ABR) fed with low-strength domestic sewage. Front. Environ. Sci. Eng. 2014, 9, 352-364. [CrossRef]

11. Smith, A.L.; Stadler, L.B.; Love, N.G.; Skerlos, S.J.; Raskin, L. Perspectives on anaerobic membrane bioreactor treatment of domestic wastewater: A critical review. Bioresour. Technol. 2012, 122, 149-159. [CrossRef] [PubMed] 
12. Gouveia, J.; Plaza, F.; Garralon, G.; Fdzpolanco, F.; Pena, M. Long-term operation of a pilot scale anaerobic membrane bioreactor (AnMBR) for the treatment of municipal wastewater under psychrophilic conditions. Bioresour. Technol. 2015, 185, 225-233. [CrossRef] [PubMed]

13. Jo, Y.; Kim, J.; Hwang, S.; Lee, C. Anaerobic treatment of rice winery wastewater in an upflow filter packed with steel slag under different hydraulic loading conditions. Bioresour. Technol. 2015, 193, 53-61. [CrossRef] [PubMed]

14. Gannoun, H.; Khelifi, E.; Omri, I.; Jabari, L.; Fardeau, M.-L.; Bouallagui, H.; Godon, J.-J.; Hamdi, M. Microbial monitoring by molecular tools of an upflow anaerobic filter treating abattoir wastewaters. Bioresour. Technol. 2013, 142, 269-277. [CrossRef] [PubMed]

15. Gannoun, H.; Othman, N.B.; Bouallagui, H.; Moktar, H. Mesophilic and thermophilic anaerobic co-digestion of olive mill wastewaters and abattoir wastewaters in an upflow anaerobic filter. Ind. Eng. Chem. Res. 2007, 46, 6737-6743. [CrossRef]

16. Couto, E.D.A.D.; Calijuri, M.L.; Assemany, P.P.; Santiago, A.D.F.; Lopes, L.S. Greywater treatment in airports using anaerobic filter followed by uv disinfection: An efficient and low cost alternative. J. Clean. Prod. 2015, 106, 372-379. [CrossRef]

17. Wu, Y.; Zhu, W.; Lu, X. Identifying key parameters in a novel multistep bio-ecological wastewater treatment process for rural areas. Ecol. Eng. 2013, 61, 166-173. [CrossRef]

18. Tonon, D.; Tonetti, A.L.; Coraucci Filho, B.; Bueno, D.A.C. Wastewater treatment by anaerobic filter and sand filter: Hydraulic loading rates for removing organic matter, phosphorus, pathogens and nitrogen in tropical countries. Ecol. Eng. 2015, 82, 583-589. [CrossRef]

19. Lew, B.; Tarre, S.; Beliavski, M.; Green, M. Anaerobic degradation pathway and kinetics of domestic wastewater at low temperatures. Bioresour. Technol. 2009, 100, 6155-6162. [CrossRef] [PubMed]

20. Dutta, K.; Tsai, C.-Y.; Chen, W.-H.; Lin, J.-G. Effect of carriers on the performance of anaerobic sequencing batch biofilm reactor treating synthetic municipal wastewater. Int. Biodeterior. Biodegrad. 2014, 95, 84-88. [CrossRef]

21. Han, Z.; Chen, F.; Zhong, C.; Zhou, J.; Wu, X.; Yong, X.; Zhou, H.; Jiang, M.; Jia, H.; Wei, P. Effects of different carriers on biogas production and microbial community structure during anaerobic digestion of cassava ethanol wastewater. Environ. Technol. 2016, 1-10. [CrossRef] [PubMed]

22. Bodkhe, S. Development of an improved anaerobic filter for municipal wastewater treatment. Bioresour.Technol. 2008, 99, 222-226. [CrossRef] [PubMed]

23. De Oliveira Cruz, L.M.; Stefanutti, R.; Coraucci Filho, B.; Tonetti, A.L. Coconut shells as filling material for anaerobic filters. SpringerPlus 2013, 2, 655. [CrossRef] [PubMed]

24. Esmaeili, A.; Beni, A.A. Novel membrane reactor design for heavy-metal removal by alginate nanoparticles. J. Ind. Eng. Chem. 2015, 26, 122-128. [CrossRef]

25. Seib, M.D.; Berg, K.J.; Zitomer, D.H. Influent wastewater microbiota and temperature influence anaerobic membrane bioreactor microbial community. Bioresour. Technol. 2016, 216, 446-452. [CrossRef] [PubMed]

26. Mckeown, R.M.; Hughes, D.; Collins, G.; Mahony, T.; Flaherty, V.O. Low-temperature anaerobic digestion for wastewater treatment. Curr. Opin. Biotechnol. 2012, 23, 444-451. [CrossRef] [PubMed]

27. Enright, A.-M.; Collins, G.; O'Flaherty, V. Temporal microbial diversity changes in solvent-degrading anaerobic granular sludge from low-temperature $\left(15{ }^{\circ} \mathrm{C}\right)$ wastewater treatment bioreactors. Syst. Appl. Microbiol. 2007, 30, 471-482. [CrossRef] [PubMed]

28. Gomec, C.Y.; Letsiou, I.; Ozturk, I.; Eroglu, V.; Wilderer, P.A. Identification of archaeal population in the granular sludge of an uasb reactor treating sewage at low temperatures. J. Environ. Sci. Heal. A. 2008, 43, 1504-1510. [CrossRef] [PubMed]

29. Gao, W.; Leung, K.; Qin, W.; Liao, B. Effects of temperature and temperature shock on the performance and microbial community structure of a submerged anaerobic membrane bioreactor. Bioresour. Technol. 2011, 102, 8733-8740. [CrossRef] [PubMed]

30. Regueiro, L.; Carballa, M.; Lema, J.M. Outlining microbial community dynamics during temperature drop and subsequent recovery period in anaerobic co-digestion systems. J. Biotechnol. 2014, 192, 179-186. [CrossRef] [PubMed]

31. Abubakkar, S.; Kundu, K.; Sreekrishnan, T.R. Comparative study of the performance of an anaerobic rotating biological contactor and its potential to enrich hydrogenotrophic methanogens. J. Chem. Technol. Biotechnol. 2015, 90, 398-406. [CrossRef] 
32. Takai, K.; Horikoshi, K. Rapid detection and quantification of members of the archaeal community by quantitative pcr using fluorogenic probes. Appl. Environ. Microbiol. 2000, 66, 5066-5072. [CrossRef] [PubMed]

33. McElhoe, J.A.; Holland, M.M.; Makova, K.D.; Su, M.S.-W.; Paul, I.M.; Baker, C.H.; Faith, S.A.; Young, B. Development and assessment of an optimized next-generation DNA sequencing approach for the mtgenome using the Illumina Miseq. Forensic Sci. Int. Genet. 2014, 13, 20-29. [CrossRef] [PubMed]

34. American Public Health Association (APHA). Standard Methods for the Examination of Water and Wastewater; American Public Health Association: Washington, DC, USA, 2005.

35. Krishna, G.V.T.G.; Kumar, P.; Kumar, P. Treatment of low strength complex wastewater using an anaerobic baffled reactor (ABR). Bioresour. Technol. 2008, 99, 8193-8200. [CrossRef] [PubMed]

36. Shin, C.; Mccarty, P.L.; Kim, J.; Bae, J. Pilot-scale temperate-climate treatment of domestic wastewater with a staged anaerobic fluidized membrane bioreactor (SAF-MBR). Bioresour. Technol. 2014, 159, 95-103. [CrossRef] [PubMed]

37. Sharma, M.K.; Khursheed, A.; Kazmi, A.A. Modified septic tank-anaerobic filter unit as a two-stage onsite domestic wastewater treatment system. Environ. Technol. 2014, 35, 2183-2193. [CrossRef] [PubMed]

38. Hermansson, M. The DLVO theory in microbial adhesion. Colloids Surf. B: Biointerfaces 1999, 14, $105-119$. [CrossRef]

39. Fang, H.H.; Chan, K.-Y.; Xu, L.-C. Quantification of bacterial adhesion forces using atomic force microscopy (AFM). J. Microbiol. Methods 2000, 40, 89-97. [CrossRef]

40. Fernández, N.; Díaz, E.E.; Amils, R.; Sanz, J.L. Analysis of microbial community during biofilm development in an anaerobic wastewater treatment reactor. Microb. Ecol. 2008, 56, 121-132. [CrossRef] [PubMed]

41. Lettinga, G.; Rebac, S.; Zeeman, G. Challenge of psychrophilic anaerobic wastewater treatment. Trends Biotechnol. 2001, 19, 363-370. [CrossRef]

42. Mckeown, R.M.; Scully, C.; Enright, A.; Chinalia, F.A.; Lee, C.; Mahony, T.; Collins, G.; Oflaherty, V. Psychrophilic methanogenic community development during long-term cultivation of anaerobic granular biofilms. ISME J. 2009, 3, 1231-1242. [CrossRef] [PubMed]

43. Bialek, K.; Kumar, A.; Mahony, T.; Lens, P.N.L.; Flaherty, V.O. Microbial community structure and dynamics in anaerobic fluidized-bed and granular sludge-bed reactors: Influence of operational temperature and reactor configuration. Microb. Biotechnol. 2012, 5, 738-752. [CrossRef] [PubMed]

44. Fey, A.; Conrad, R. Effect of temperature on carbon and electron flow and on the archaeal community in methanogenic rice field soil. Appl. Environ. Microbiol. 2000, 66, 4790-4797. [CrossRef] [PubMed]

45. Smith, A.L.; Skerlos, S.J.; Raskin, L. Psychrophilic anaerobic membrane bioreactor treatment of domestic wastewater. Water Res. 2013, 47, 1655-1665. [CrossRef] [PubMed]

46. Mchugh, S.; Carton, M.W.; Collins, G.; Oflaherty, V. Reactor performance and microbial community dynamics during anaerobic biological treatment of wastewaters at 16-37 ${ }^{\circ} \mathrm{C}$. FEMS Microbiol. Ecol. 2004, 48, 369-378. [CrossRef]

47. Sundberg, C.; Al-Soud, W.A.; Larsson, M.; Alm, E.; Yekta, S.S.; Svensson, B.H.; Sørensen, S.J.; Karlsson, A. 454 pyrosequencing analyses of bacterial and archaeal richness in 21 full-scale biogas digesters. FEMS Microbiol. Ecol. 2013, 85, 612-626. [CrossRef] [PubMed]

48. Lee, S.H.; Kang, H.J.; Lee, Y.H.; Lee, T.J.; Han, K.; Choi, Y.; Park, H.D. Monitoring bacterial community structure and variability in time scale in full-scale anaerobic digesters. J. Environ. Monit. 2012, 14, 1893-1905. [CrossRef] [PubMed]

49. Goux, X.; Calusinska, M.; Lemaigre, S.; Marynowska, M.; Klocke, M.; Udelhoven, T.; Benizri, E.; Delfosse, P. Microbial community dynamics in replicate anaerobic digesters exposed sequentially to increasing organic loading rate, acidosis, and process recovery. Biotechnol. Biofuels 2015, 8, 122. [CrossRef] [PubMed]

50. Chebbi, A.; Mnif, S.; Mhiri, N.; Jlaiel, L.; Sayadi, S.; Chamkha, M. A moderately thermophilic and mercaptan-degrading bacillus licheniformis strain can55 isolated from gas-washing wastewaters of the phosphate industry, Tunisia. Int. Biodeterior. Biodegrad. 2014, 94, 207-213. [CrossRef]

51. Nakkabi, A.; Sadiki, M.; Fahim, M.; Ittobane, N.; Ibnsoudakoraichi, S.; Barkai, H.; Abed, S.E. Biodegradation of Poly(ester urethane)s by Bacillus subtilis. Int. J. Environ. Res. 2015, 9, 157-162.

52. Patowary, K.; Saikia, R.R.; Kalita, M.C.; Deka, S. Degradation of polyaromatic hydrocarbons employing biosurfactant-producing Bacillus pumilus KS2. Ann. Microbiol. 2014, 65, 225-234. [CrossRef] 
53. Xiao, Y.; Chen, S.; Gao, Y.; Hu, W.; Hu, M.; Zhong, G. Isolation of a novel beta-cypermethrin degrading strain Bacillus subtilis BSF01 and its biodegradation pathway. Appl. Microbiol. Biotechnol. 2014, 99, 2849-2859. [CrossRef] [PubMed]

54. Dhall, P.; Kumar, R.; Kumar, A. Biodegradation of sewage wastewater using autochthonous bacteria. Sci. World J. 2012, 2012, 861903. [CrossRef] [PubMed]

55. Antwi, P.; Li, J.; Boadi, P.O.; Meng, J.; Shi, E.; Xue, C.; Zhang, Y.; Ayivi, F. Functional bacterial and archaeal diversity revealed by $16 \mathrm{~S}$ rRNA gene pyrosequencing during potato starch processing wastewater treatment in an UASB. Bioresour. Technol. 2017, 235, 348-357. [CrossRef] [PubMed]

56. Xie, Z.; Wang, Z.; Wang, Q.; Zhu, C.; Wu, Z. An anaerobic dynamic membrane bioreactor (AnMBR) for landfill leachate treatment: Performance and microbial community identification. Bioresour. Technol. 2014, 161, 29-39. [CrossRef] [PubMed]

57. Sun, W.; Yu, G.; Louie, T.S.; Liu, T.; Zhu, C.; Xue, G.; Gao, P. From mesophilic to thermophilic digestion: The transitions of anaerobic bacterial, archaeal, and fungal community structures in sludge and manure samples. Appl. Microbiol. Biotechnol. 2015, 99, 10271-10282. [CrossRef] [PubMed]

58. Tang, Y.; Shigematsu, T.; Morimura, S.; Kida, K. Microbial community analysis of mesophilic anaerobic protein degradation process using bovine serum albumin (BSA)-fed continuous cultivation. J. Biosci. Bioeng. 2005, 99, 150-164. [CrossRef] [PubMed]

59. Regueiro, L.; Lema, J.M.; Carballa, M. Key microbial communities steering the functioning of anaerobic digesters during hydraulic and organic overloading shocks. Bioresour. Technol. 2015, 197, 208-216. [CrossRef] [PubMed]

60. Resende, J.A.; Silva, V.L.D.; De Oliveira, T.L.R.; Fortunato, S.; Carneiro, J.D.C.; Otenio, M.H.; Diniz, C.G. Prevalence and persistence of potentially pathogenic and antibiotic resistant bacteria during anaerobic digestion treatment of cattle manure. Bioresour. Technol. 2014, 153, 284-291. [CrossRef] [PubMed]

(C) 2017 by the authors. Licensee MDPI, Basel, Switzerland. This article is an open access article distributed under the terms and conditions of the Creative Commons Attribution (CC BY) license (http://creativecommons.org/licenses/by/4.0/). 